Int. J. Electrochem. Sci., 14 (2019) 10139 - 10152

\title{
Electrochemical mechanism of 317L stainless steel under biofilms with coexistence of iron-oxidizing bacteria and sulfate- reducing bacteria
}

\author{
Haiya Zhang ${ }^{1,2}$, Yimei Tian ${ }^{1, *}$, Mengxin Kang ${ }^{l}$, Shichao Jia ${ }^{1}$ \\ ${ }^{1}$ School of Environmental Science and Engineering, Tianjin University, Tianjin, 300350, China \\ ${ }^{2}$ School of Environment, Tsinghua University, Beijing 100084, China \\ *E-mail: ymtian 2000@126.com
}

doi: $10.20964 / 2019.11 .07$

Received: 14 April 2019 / Accepted: 22 August 2019 / Published: 7 October 2019

The corrosion behavior of 317L stainless steel (SS) in the presence of biofilms with coexistence of ironoxidizing bacteria (IOB) and sulfate-reducing bacteria (SRB) was investigated by polarization curves and electrochemical impendence spectra. Results showed that the corrosion mechanisms varied with the bacterial evolution process. the lower dissolved oxygen (DO) concentration caused by the IOB multiplication in reclaimed water induced the ennoblement of $\mathrm{E}_{\text {corr }}$ and the increase of electron transfer resistance due to the fact that DO using as the only depolarization agent. Meanwhile, the deposition of an outer IOB biofilm, iron hydroxide layer and an inner chromium oxide layer on the 317L SS protected the metal surface and retarded the corrosion process. However, as the SRB proliferation the cathode depolarization process was promoted by SRB metabolic activity after 5 days and the preformed twolayer films were converted into one layer induced by the sulfidation effect, enhancing the electron transfer process correspondingly. Furthermore, the uneven metabolisms distribution, gradients of sulfate ions and DO concentration and heterogeneous biofilm structure induced larger localized corrosion of 317L SS by biofilm in reclaimed water.

Keywords: electrochemical corrosion mechanisms; 317L stainless steel; biofilm; IOB; SRB; reclaimed water

\section{FULL TEXT}

(C) 2019 The Authors. Published by ESG (www.electrochemsci.org). This article is an open access article distributed under the terms and conditions of the Creative Commons Attribution license (http://creativecommons.org/licenses/by/4.0/). 